\title{
Parenting and physical punishment: primary care interventions in Latin America
}

\author{
Carmen López Stewart, ${ }^{1}$ Miriam George Lara, ${ }^{1}$ Luis Diego Herrera \\ Amighetti, ${ }^{2}$ Lawrence S. Wissow, ${ }^{3}$ Maria Isabel Gutierrez, ${ }^{4}$ \\ Itzhak Levav, ${ }^{5}$ and Matilde Maddaleno ${ }^{6}$
}

ABSTRACT Physical punishment is a form of intrafamilial violence associated with short-and long-term adverse mental health outcomes. Despite these possible consequences, it is among the most common forms of violent interpersonal behavior. For many children it begins within the first year of life. The goal of this study was to determine the feasibility of involving public sector primary health care providers to inform parents about alternatives to physical punishment. The study used a qualitative design utilizing focus groups and survey questionnaires with parents and providers at six clinic sites chosen to be representative of public sector practice settings in Costa Rica and in metropolitan Santiago, Chile. The data were collected during 1998 and 1999. In the focus groups and surveys the parents voiced a range of opinions about physical punishment. Most acknowledged its common use but listed it among their least preferred means of discipline. Frequency of its use correlated positively with the parents' belief in its effectiveness and inversely with their satisfaction with their children's behavior. Some parents wanted to learn more about discipline; others wanted help with life stresses they felt led them to use physical punishment. Parents reported they chose other family members more frequently as a source of parenting information than they did health care providers. Some parents saw providers as too rushed and not knowledgeable enough to give good advice. Providers, in turn, felt ill equipped to handle parents' questions, but many of the health professionals expressed interest in more training. Parents and providers agreed that problems of time, space, and resources were barriers to talking about child discipline in the clinics. Many parents and providers would welcome a primary-care-based program on physical punishment. Such a program would need to be customized to accommodate local differences in parent and provider attitudes and in clinic organization. Health care professionals need more training in child discipline and in the skills required to interact with parents on issues relating to child behavior.

Interpersonal violence is one of the major public health problems in Latin
America. To cite only one measure, in Brazil, Mexico, the Andean countries,
1 República de Chile, Ministerio de Salud, Unidad de Salud Mental, Santiago, Chile.

2 Hospital CIMA-San José, Department of Psychiatry, San José, Costa Rica.

3 Johns Hopkins University School of Hygiene and Public Health, Baltimore, Maryland, United States of America. Send correspondence to: Larry Wissow, JHU School of Hygiene and Public Health, 749 Hampton House, 624 N. Broadway, Baltimore, Maryland 21205, United States of America; e-mail: Lwissow@jhsph.edu

\footnotetext{
4 Escuela de Salud Pública, Universidad del Valle, Cali, Colombia (at the time of the study was with the Johns Hopkins University School of Hygiene and Public Health, Baltimore, Maryland, United States of America).

5 Israel, Ministry of Health, Jerusalem, Israel (at the time of the study was with the Pan American Health Organization, Washington, D.C., United States of America).

6 Pan American Health Organization, Washington, D.C., United States of America.
}

Central America, and the Latin Caribbean, homicide is one of the top ten causes of years of potential life lost (1). Many factors are thought to contribute to this situation, including the intergenerational transmission of violent behavior (2). Although not all studies agree on mechanisms or extent, families seem capable of maintaining a "cycle of violence," in which children grow up to replicate the physically violent behavior they experience or witness within their homes $(3,4)$. 
Some, but not all, students of child development feel that physical punishment, though assumed to be in the best interests of children, forms a part of this cycle of violence (5-8) and contributes to the prevalence of affective disorders and substance abuse among adults (9). Parents in many countries practice physical punishment. A Gallup Organization survey of parents in the United States of America found that $47 \%$ said they had spanked their child with a hand in the past year, and $21 \%$ had spanked their child with a belt or other object (10). In a study of parents in Madrid, Spain, and seven Latin American cities, on average 15\% of the men and $24 \%$ of the women in those cities reported they had spanked a child in the last month (11).

Concerns about physical punishment have led to efforts throughout the world-most prominently in Scandinavia, and recently in Israel-to influence parents to adopt other means of disciplining children. These efforts have taken many forms, including media campaigns, community organizing, development of educational materials, and legislation (12). In 1995 the Pan American Health Organization proposed using primary medical providers as catalysts for communitybased programs to reduce the use of physical punishment (13).

Data from the United States suggest that the use of physical punishment starts very early, before a child's first or second birthday, when children are physically and emotionally most vulnerable (14). Primary care providers interact with families from the child's first days of life, and thus may be in a position to influence parents' practices. In the two countries in which the present study was performed-Chile and Costa Rica-primary care services reach over $90 \%$ of children $(15,16)$.

Data from the United States, however, suggest that it may not be easy to introduce new child behavior or development content into pediatric primary care. Surveys of parents find that many hesitate to discuss psychosocial concerns because they believe their pediatrician to be unqualified, uninterested, or too busy (17). Surveys of pe- diatricians find that they discuss child discipline less frequently than they discuss such issues as growth or acute illness, that they have less confidence that they could provide guidance on behavioral issues, and that they have lower expectations that they could prevent problems in this area (18). Changes in health care financing have pushed physicians to see more patients, shorten visits, and trim content from those visits rather than add new responsibilities $(19,20)$.

Our study examined the feasibility of involving public sector primary care providers in an effort to reduce parents' use of physical punishment. The study objectives were to determine:

- parents' attitudes about physical punishment, and their general receptivity to learning alternative methods

- if parents using community clinics would be receptive to learning from health professionals at the clinics

- if providers at the clinics felt capable of counseling parents about child discipline

- if providers at the clinics were interested in further training on child behavior and discipline

\section{METHODS}

The study used a qualitative crosssectional design applying focus groups and written survey questionnaires. The data were collected at six clinics typical of public sector practice settings, four in Costa Rica and two in metropolitan Santiago, Chile. The written surveys were used with parents and with clinic health professionals in both countries. Focus groups were used with parents in Chile and in Costa Rica, but with health professionals only in Costa Rica.

The study protocols were approved by the Ministry of Health of Chile and by the National Children's Hospital in Costa Rica. Parents were asked to give verbal consent for participation. No identifying information was collected on the written questionnaires, and during the focus groups the parents and professionals identified themselves only by first name.

\section{Clinic populations}

Of the two clinics studied in the Santiago, Chile, metropolitan area, one served a community that was among the region's poorest. The 1997 infant mortality rate in that community was 42.02/100 000 (21). The other clinic served a community that was among the most affluent of those using public sector medical services. That community had an infant mortality rate of $7.48 / 100$ 000. (For comparison, the average infant mortality rate for the entire Santiago metropolitan region was 6.93/100 000).

In Costa Rica, all four of the clinics were operated by the Costa Rican Social Security Fund. One served a transitional farming community near the Pacific coast. This community had a low population density, about 370 persons $/ \mathrm{km}^{2}$, and a relatively low infant mortality rate, 6.9/100 000 (22). Another clinic, serving a largely urban working class community, had a population density of 4407 persons $/ \mathrm{km}^{2}$ and a higher infant mortality rate, 17.6/100 000. A third clinic also served an urban community with a high population density, 3979 persons $/ \mathrm{km}^{2}$, and a high infant mortality rate, 15.0/ 100 000. The fourth clinic served a rural area experiencing an economic upswing. Population density here was just 24 persons $/ \mathrm{km}^{2}$ but infant mortality was high, 18.0/100 000 .

For the survey questionnaire in the two countries, research assistants recruited parents sequentially in the clinic waiting areas. The only requirement for inclusion was that the parent had come to the clinic on a day the study was being conducted. There were no exclusion criteria, and no attempt was made to document the proportion or characteristics of parents who declined to participate.

In total at the six sites, 279 parents completed a survey questionnaire, 161 in Chile and 118 in Costa Rica. The 161 Chilean parents included 145 mothers $(89 \%), 5$ fathers $(3 \%)$, and 6 grand- 
mothers (4\%). Among the 118 parents in Costa Rica were 94 mothers $(80 \%)$, 14 fathers $(12 \%)$, and 6 grandmothers (5\%). These proportions are in line with estimates regarding the relationship of adults to children making pediatric visits at the study sites.

At each of the six clinics, a separate set of parents was recruited to participate in a focus group, with a targeted group size of 6 to 10 persons (23). The focus group composition was intended to reflect the population of parents accompanying children to pediatric visits. Therefore, while recruiters did not exclude fathers, in some cases none of the fathers among the relatively few present agreed to participate. The focus groups in Chile were composed solely of mothers, 6 in one group and 9 in the other. In Costa Rica two of the focus groups consisted only of mothers, and two had both mothers and fathers. The number of participants in the Costa Rican groups ranged from 6 to 11 .

A total of 122 health care providers52 in Chile and 70 in Costa Rica-completed a survey that paralleled the questions asked of parents. Of the 52 Chilean providers, 14 (27\%) were physicians, 13 (25\%) were nurses, 10 (19\%) were dentists, and 7 (13\%) were social work assistants. Among the 70 providers in Costa Rica were 18 health auxiliaries (26\%), 17 physicians (24\%), 6 clerical staff members (9\%), 5 clinic laboratory workers (7\%), 5 pharmacists or pharmacy technicians (7\%), 4 nurses (6\%), 4 dentists or dental assistants $(6 \%)$, and 3 social workers (4\%).

In Costa Rica, a different set of providers was recruited to participate in focus groups at each of the four clinics. A total of 31 providers participated, with groups ranging in size from 6 to 9 professionals.

\section{Survey questionnaires}

The survey questionnaires used in the study were developed in Chile. After field testing in Costa Rica, the team there reworded some questions and changed response formats. Some changes involved local vocabulary, such as substituting carros y buses as examples of vehicular traffic in Costa Rica for the autos y micros phrase used in Chile, or substituting the word clinica for consultorio. Other changes involved changing the response format, as explained below. A copy of the questionnaire used with the parents in Chile is included in Annex 1 of this article.

Questionnaires were self-administered. After parents provided some basic demographic information, they assessed vignettes presenting three hypothetical situations involving a child aged 2 to 5 years old: running into the street, hitting other children, and refusing to go to bed. These questions were derived from McCormick's survey of primary care providers in the United States (24). Parents were asked if this had ever happened with their child, and what, in each situation, they thought a parent should do. In Chile, they were given three possible responses, one of which included spanking (pegar), and asked to indicate how often they felt parents should use each response (never, sometimes, or always). In Costa Rica, the parents were presented three or four possible responses to the child's action, one of which included spanking, and asked to select the single response they felt a parent should use.

In the next questionnaire section, parents examined a list of common disciplinary practices and noted which they used. No mention was made of child age or gender. An identical list followed, but this time parents were asked which practices they felt were useful or effective. The questionnaire concluded with a section on sources of information about child discipline and opinions about seeking help for discipline from the medical clinic. Questionnaire items related to the use of physical punishment had good internal reliability (alpha of .62 in Costa Rica and .74 in Chile).

The clinic professionals were asked to complete a parallel questionnaire that asked their opinions about the use of physical punishment and what they perceived to be the opinions held by parents. The professionals' survey also included a section on their interest in further training and on the conditions in the clinics related to counseling; a copy of that second questionnaire section, as used in Chile, is given in Annex 2.

\section{Focus groups}

The parent focus groups used a discussion guide designed to elicit parent beliefs about influences on child development, relationships between children and parents, effective means of controlling child behavior, and the use of physical punishment. Leaders (a psychologist assisted by a psychology student as observer) began the discussion by asking a general question about raising children, "What do you do to teach children behavior, so that they will do basic things like washing their hands, how to get dressed, etc.?" As the discussion evolved, parents described how they educated children and controlled behavior. When parents used words that indicated some form of physical contact with the child, the focus group leaders asked the parents to talk more about how and when they would use that particular intervention. However, the leaders did not try to elicit precise definitions of the words, nor to rate the chosen words according to the potential for injury or some other ranking of violence. Table 1 lists the words used by parents for various forms of physical punishment.

The professional focus groups in Costa Rica were designed to elicit opinTABLE 1. Words used by parents to de-
scribe forms of physical punishment

cachetadas (slaps on the face)

coscos (raps)

fajazos (hit with a belt)

jalar el pelo (pull hair)

jalón de orejas (a pull on the ears)

mangazos, mangazos por la boca (slap on the mouth)

palmazos, palmadas (slaps)

patadas (kicks)

pegar con palo (hit with a stick)

pegar en el traste (hit on the bottom)

pellizcos (pinches) 
ions on advising parents on discipline, parent attitudes, professional training, professional roles, and clinic logistics.

\section{Analysis of questionnaires and focus groups}

Parent and provider focus groups were audio tape recorded and then transcribed by local assistants fluent in Spanish and familiar with the terms that the participants used. Transcriptions were then summarized in less colloquial Spanish, with illustrative quotations included in the summaries. We next developed a "coding guide" built around our main study questions. The focus group summaries were coded using the guide, and files were created containing excerpts from the summaries and quotations from the original transcripts pertaining to each of the major study questions. We then analyzed questionnaire data corresponding to the major study questions, and combined those results with the focus group data files. As a check on the analytic process, we discussed final conclusions with one of the authors (MIG), who had reviewed the original focus group transcripts.

\section{RESULTS}

\section{Is physical punishment sufficiently common to warrant attention?}

In all the focus groups, physical punishment was said to be a common phenomenon that, for many, was a relatively normal and necessary tool for correcting and educating children. The "normal" nature of physical punishment was also reflected in questionnaire responses. In Chile, for the three hypothetical vignettes (runs into the street, hits other children, or refuses to go to bed), from $23 \%$ to $45 \%$ of parents said a parent should sometimes or always hit the child. The child who did not want to go to bed was the least likely to be hit, and the child who ran out in the street the most likely. In Costa Rica (where parents were able to list only one response, the one they thought was best), $6 \%$ said a child should be punished physically for running into the street, $13 \%$ recommended this response for hitting other children, and $3 \%$ suggested it for refusing to go to bed. When asked in relationship to their own children, $51 \%$ of Chilean parents said they sometimes (a veces) hit in order to control their children when they misbehaved, and $1 \%$ said they used hitting frequently (siempre). In Costa Rica, 20\% said they hit often ( $a$ menudo) to control their children when they misbehaved and 5\% said they did very frequently (muy frecuentemente). In both countries, the clinics did not differ significantly from each other in the proportion of parents who said they hit often or frequently.

\section{How strongly do parents endorse physical punishment?}

In the surveys and focus groups, parents consistently emphasized that with children they preferred using positive interactions (complements, rewards), explanations, and nonphysical punishments rather than physical punishment. As one parent from the more affluent of the Chilean clinics said, "I think that if you talk patiently, clearly, and firmly to children [then] you don't have a problem." In all of the focus groups, parents qualified their statements in support of physical punishment by adding that it should always be carried out calmly and in moderation, not out of anger or irritation. One parent said that physical punishment should always be followed by an explanation and telling the child he or she is loved.

Some parents, however, felt that children should never be hit. They saw physical punishment as a form of aggression that didn't teach anything, scared children, and harmed a child's personality. In both countries, some of the parents in the focus groups said that they experienced regret after using physical punishment. They voiced concern that the results of physical punishment were unpredictable and could cause children to get "off track" when they reached adolescence.

\section{Why do parents use physical punishment?}

Parents cited frustration with children and irritation with partners as primary reasons they resorted to physical punishment. In the Costa Rica survey data, parents' lack of satisfaction with their children's obedience (a question asked only in Costa Rica) was correlated with the use of physical punishment. Of 92 Costa Rican parents who said they were satisfied or very satisfied with their children's obedience, $17(18 \%)$ said that they hit often or very frequently. In contrast, of 23 parents who said they were unsatisfied or very unsatisfied with their children's behavior, 13 (57\%) said they hit sometimes or frequently $(P<0.001)$.

A second major justification was that parents found physical punishment to be effective. Many had experienced physical punishment themselves as children. They said they had deserved it and it did them good. Other parents felt that at times that hitting was "the only thing that children hear." Another parent paraphrased the Bible: "Correct your child and it will give you peace." The survey data showed that parents who used more physical punishment believed more strongly that it was useful. Among Costa Rican parents who indicated that hitting was effective, $50 \%$ (18 of 36) said they used it sometimes or very frequently, compared to $15 \%$ of parents (12 of 82 ) who did not think it was effective $(P<0.0001)$. In Chile, $89 \%$ of parents (31 of 35 ) who said that hitting was sometimes or always effective reported that they sometimes (a veces) or frequently (siempre) hit their children, when their child misbehaved, compared to $28 \%$ of parents who said that hitting was never useful $(21 / 76)(P<0.0001)$.

\section{Do parents want information about alternatives to physical punishment?}

In the focus groups, parents voiced a wide range of attitudes toward learning about alternatives to physical punishment. At one extreme, parents at the 
most rural and disadvantaged Costa Rican clinic felt they definitely needed more information about discipline, educating children, and other aspects of child-rearing. They remarked that no one had taught them about this difficult task. In contrast, parents at the lower-income clinic in Chile expressed little interest in receiving more education and counseling about discipline. At the more affluent Chilean site, parents were interested in discipline but saw it as an issue that would resolve itself if they could get help with problems contributing to stress, such as unemployment, child care, relationships with their spouse, and absent fathers. Parents at an urban Costa Rican clinic took a middle position. They said they were interested in alternatives to physical punishment but had to be convinced first that the alternatives would work. They worried what they would do if they got to the point where "[the children] aren't listening despite everything you have tried."

\section{Have parents asked for help with child discipline?}

Of the parents completing the study survey $43 \%$ of those in Chile and $41 \%$ of those in Costa Rican said they had asked someone for help with child discipline. In both countries, family members were the most frequently listed resource $(51 \%$ in Chile, $50 \%$ for Costa Rica). Only $20 \%$ of the parents in Costa Rica and $18 \%$ of them in Chile said they had asked a health professional. In focus groups parents named several ways in which they would like to get more information. In both countries parents said they liked health education programs on radio and television. Parents at three of the four Costa Rican sites said they enjoyed such clinic activities as talks, conferences, or lectures, but that they would also like more opportunities for personal consultations with health professionals. At the rural Costa Rican site with low infant mortality, parents talked about organizing a community-based group to continue their focus group discussion.
Parents in both countries noted barriers to asking clinic health care providers for help with discipline. At the more affluent clinic in Chile, parents said they hesitated because there was limited privacy in the clinics; if they were overheard, their neighbors might consider them punitive. Chilean parents were concerned about the stigma of being referred to a psychologist. As one mother said, "[Others think] that if the child goes to see a psychologist, you are crazy." However, parents at an urban Costa Rican clinic said they wanted more access to clinic psychologists because not everyone could afford to see one in private practice.

Remarks by Costa Rican parents reflected the activity of children's rights and child abuse prevention activities in their country. At both of the urban Costa Rican clinics, parents expressed irritation with what they saw as the emphasis on children's rights without regard to either children's duties or the rights of parents. Parents at one of the urban clinics said they were afraid they would be reported as suspected child abusers if it was known that they used physical punishment. Neither of these issues was raised by Chilean parents.

\section{How do parents feel about talking with health professionals?}

Parents in the Costa Rican focus groups were critical of health professionals in general and doctors in particular. Some said they felt the professionals did not have enough training to talk about child behavior and didn't give good answers to parent questions. At three of the sites, parents criticized doctors for not spending enough time with them. Many doctors, they said, only gave them prescriptions and then sent them away. They felt that there were doctors who didn't seem to like their profession, and who were crude or harsh. At the rural clinic with a low infant mortality rate, parents were concerned about the lack of continuity of care. "They (the doctors) might give advice, but sometimes you might never see them again."

\section{Provider attitudes toward counseling parents about physical punishment}

Agreeing with parents, providers considered themselves ill equipped to handle problems of child behavior and discipline. In Chile, where the providers were asked to answer the question "yes" or "no," 77\% of them said they did not have enough training to handle parents' questions. There was no significant difference on this issue among the different categories of clinic professionals. In Costa Rica, where the providers could answer "never," "sometimes," or "often," $11 \%$ of them said they never felt adequately trained for these kinds of questions, and 59\% said they sometimes felt adequately trained.

These feelings were echoed in the focus group discussions among providers in Costa Rica. The providers said they didn't feel confident in the answers they gave to parents' questions, and avoided answering out of fear of giving bad advice. Providers identified time limitations as the biggest structural barrier to working with parents on child discipline. Physicians in one clinic noted that when they took extra time with parents to discuss behavior and discipline, they got behind in their regular work. Nevertheless, they felt they were doing something important. Space was another problem. The providers agreed with parents that privacy was limited in the clinics, as was space to see parents without the child present or for consultations by visiting specialists. Other barriers included a lack of referral resources and educational materials to give to parents. However, the overwhelming majority of providers surveyed- $87 \%$ in Costa Rica and $89 \%$ in Chile-felt that talking with parents about discipline was part of their responsibility. In Costa Rica this included 14 of the 17 physicians participating in the survey; in Chile it included all 14 of the physicians participating. Similarly, $96 \%$ of Chilean providers and $93 \%$ of those in Costa Rica said they would be interested in getting more training in behavior and discipline. 


\section{Providers' own attitudes toward corporal punishment}

In focus groups and individual interviews, providers voiced a range of approaches to raising children. For example, at the rural Costa Rican health center with a low infant mortality rate, providers were split between those who took a more "rights-oriented" approach, seeing children as intelligent persons with the same dignity and capacities as adults, and those who saw children as inexperienced, who didn't listen when talked to, and who needed to learn the rules and laws of society, via punishment if need be. The more rights-oriented providers used their position to support the belief that children should not be hit. They posed the question of whether adults, if they put themselves in the place of children, would be willing to be physically punished. Providers at an urban clinic labeled any form of physical punishment as "aggression" that could generate a violent or rebellious response.

Providers who supported physical punishment gave a variety of reasons, including their own experience as children. Like the parents, some felt that most people of their generation had been physically punished as children and grew up to become "good citizens." These providers felt that it was reasonable to talk first with children, but if children didn't behave or endangered themselves or others, then hitting was justified and effective.

\section{DISCUSSION}

Perhaps the most striking aspect of our study's results are the similarities of parent and provider attitudes to those found elsewhere in the world. As in the United States, many parents use physical punishment despite misgivings about its effectiveness, but also don't want to give it up, for fear of losing control of their children $(8,10)$. Also similar to other findings from Latin America (11) and the United States (14), belief in the effectiveness of physical punishment, and frustration or dissatisfaction with child behavior, are associated with increased use of physical punishment. In a crosssectional study such as ours, cause and effect cannot be determined. Nevertheless, different educational approaches are likely to be necessary for parents who justify hitting with a conviction that it works, compared to parents who use it despite questions about need and effectiveness. Surveys in the United States suggest that there is no one profile of parents who use physical punishment $(14,25)$.

Another parallel with studies elsewhere is the relatively low rank given by parents to medical clinics as a source of information about child behavior and discipline. Though this study was not designed to determine a precise estimate, the proportion of parents in our study saying they sought advice from the clinics was similar to the proportion found in a national survey of parents of young children conducted in the United States (14). The reasons parents in Chile and Costa Rica gave for not asking were also similar to those that other studies have found. Many parents perceive physicians to be untrained or uninterested in child behavior issues (17). Other parents feel they get inadequate time, privacy, and respect for discussion of potentially sensitive topics (26).

Our study suggests, however, that barriers might not be the same in all countries. Most striking were differences in attitudes toward psychological consultation and concerns about child abuse reporting. Parents in the Chilean focus groups were concerned about the stigma of meeting with a psychologist, while parents in Costa Rica wanted more access to psychologists. Parents in Costa Rica voiced concerns about being reported for child abuse to the country's child advocacy organization, but this concern did not come up in the Chilean discussions.

Providers strongly favored increasing clinic capacities to handle parent concerns about child discipline. Providers worried, however, that they lacked skills and could even cause harm if they intervened under present conditions. Parent comments about providers not taking the time to listen suggest that training professionals both in communication skills and in child behavior would be useful. Parent surveys and observations of parentdoctor interactions find that better physician listening skills are associated with parents asking more questions about discipline and disclosing more information about their use of physical punishment $(14,27)$.

Models of organizational change point out the need to build consensus and identify key decisionmakers if new programs are to be successfully adopted and sustained $(28,29)$. Our results suggest that there is considerable heterogeneity among providers in their attitudes towards physical punishment. As found in other studies $(24,30)$, some providers support its use while others are strongly opposed. Providers in our study advanced a variety of models for developing a program on physical punishment, ranging from focusing on health technicians, who make home visits, to having the clinic staff train as a team so that their interventions could be mutually reinforcing. This diversity suggests that each clinic will have to identify advocates and methods that suit the attitudes of local parents and providers. Clinics may ultimately find it most effective to partner with community groups interested in developing parenting education and support programs.

Our study did not try to define what Goodman and colleagues (29) call the "adopting unit," that is, the person or persons who will ultimately be able to decide if a clinic is able to take on a project related to physical punishment. Providers could always seek additional training on their own and incorporate it in their practice. Nevertheless, the health professionals in our study identified issues that require both collective action and institutional approval, including the pace of visits, educational and referral resources, clinic space, the possibility of adding new services, the philosophy of care (medical versus more holistic), and the content of undergraduate and graduate professional education.

This study has three major limitations. First, although the clinic sites 
where it was performed were chosen to be representative of the public sector primary care system in their respective countries, the number of clinics and individuals participating is small compared to the overall number of clinics and the size of the population these clinics serve. In addition, we have no knowledge of how attitudes might differ in private clinics. Professional attitudes might be similar, however, to the extent that some public sector providers also work in private clinics. A second limitation involves data collection. Although we attempted to recruit subjects systematically, data were not collected on the number and characteristics of those who declined to participate. A third limitation involves survey validity. The survey results could have reflected what respondents perceived to be desirable answers. Some evidence for this comes from comparing focus group and survey responses; support for physical punishment seems stronger and more consistent in the focus groups than in the surveys. As we learned, some parents felt they could be stigmatized by admitting that they used physical punishment. The perception may have dissuaded some from accurately completing the questionnaire. However, in focus groups, one parent's disclosure could make the practice more acceptable and encourage others to talk about their experiences more openly. Thus there is some risk that the surveys underestimated the use of physical punishment and overestimated the use of alternative strategies. However, we do have support for the validity of the parent questionnaires. The questionnaires had good internal validity, measured both statistically (Chronbach's alpha for questions relating to physical punishment) and conceptually (relationships of reported beliefs and actions, as predicted from other studies).

\section{CONCLUSIONS}

Physical punishment is a topic that evokes concern and interest among parents and health providers. A program to incorporate education about physical punishment would find advocates among both parents and providers at public sector primary care sites in urban Chile and in Costa Rica. The program would need to be customized to accommodate local differences in attitudes and clinic organization. Further work is required to identify advocates and locate resources at higher levels of each country's health care system.

Acknowledgments. Drs. Nelson Varga, Adrian Díaz, and Alberto Concha-Eastman provided helpful comments in the development of the questionnaires and protocol and in the preparation of the manuscript.

\section{REFERENCES}

1. Pan American Health Organization. Health in the Americas, 1998 edition. Washington, D.C.: PAHO; 1998.

2. McAlister A. Juvenile violence in the Americas: innovative studies in research, diagnosis, and prevention. Washington, D.C.: Pan American Health Organization; 1998.

3. Dodge KA, Bates JE, Pettit GS. Mechanisms in the cycle of violence. Science 1990;250(4988):1678-1683.

4. Hotaling GT, Straus MA, Lincoln AJ. Intrafamily violence, and crime and violence outside the family. In: Ohlin L, Tonry M, eds. Family violence. Crime and justice: a review of research, volume 11 . Chicago: University of Chicago Press; 1989. p. 315-375.

5. Seagull EA, Weinshank AB. Childhood depression in a selected group of lowachieving seventh-graders. J Clinical Child Psychol 1984;13:134-140.

6. Holmes SJ, Robins LN. The role of parental disciplinary practices in the development of depression and alcoholism. Psychiatry 1988(1);51:24-36.

7. Strassberg Z, Dodge KA, Pettit GS, Bates JE. Spanking in the home and children's subsequent aggression toward kindergarten peers. Dev Psychopathol 1994;6: 445-461.
8. Straus MA. Beating the devil out of them: corporal punishment in American families. New York: Lexington Books; 1994.

9. MacMillan HL, Boyle MH, Wong MY, Duku EK, Fleming JE, Walsh CA. Slapping and spanking in childhood and its association with lifetime prevalence of psychiatric disorders in a general population sample. CMAJ 1999;161:805-809.

10. Gallup Organization. Disciplining children in America. Princeton, New Jersey, United States: The Gallup Organization; 1995.

11. Orpinas P. Who is violent?: factors associated with aggressive behaviors in Latin America and Spain. Rev Panam Salud Publica/Pan Am J Public Health 1999; 5(4/5):232-244.

12. Ziegert KA. The Swedish prohibition of corporal punishment: a preliminary report. J Marriage Family 1983:45(4): 917926.

13. Levav I, Guerrero R, Phebo L, Coe G, Cerqueira MT. A regional effort to reduce corporal punishment in children. The promotion of a community program through primary care. Washington, D.C.: Pan American Health Organization; 1995.

14. Wissow LS. The context of child discipline in the first three years of life. In: Halfon N, Shuster M, McLaren KT, eds. The health and social conditions of young children and their families. Forthcoming.

15. Pan American Health Organization, Division of Health Systems and Services Development, Program for Organization and Management of Health Systems and Services. Chile, profile of the health services system. Washington, D.C.: PAHO; 1999.

16. Pan American Health Organization, Division of Health Systems and Services Development, Program for Organization and Management of Health Systems and Services. Costa Rica, profile of the health services system. Washington, D.C.: PAHO; 1999.

17. Hickson GB, Altemeier WA, O'Connor S. Concerns of mothers seeking care in private pediatric offices: opportunities for expanding services. Pediatrics 1983;72(5): 619-624.

18. Cheng TL, DeWitt TG, Savageau JA, O'Connor KG. Determinants of counseling in primary care pediatric practice: physician attitudes about time, money, and health issues. Arch Pediatr Adolesc Med 1999;153(6):629-635.

19. Morrell DC, Evan ME, Morris RW, Roland MO. The "five minute" consultation: effect of time constraint on clinical content and patient satisfaction. Br Med J 1986;292(6524):870-873. 
20. Freudenheim M, Krauss C. Dancing to a new health care beat: Latin America becomes ripe for U.S. companies' picking. New York Times 1999 June 16:C1, C8.

21. Chile, Instituto Nacional de Estadísticas. Anuario de demografía, 1997. Santiago de Chile: Ministerio de Salud, Servicio de Registro Civil e Identificación; 1999. p. 48, 75.

22. República de Costa Rica, Ministerio de Economía, Industria y Comercio, Instituto Nacional de Estadística y Censos. [Population figures for 1987, Tables 1 and 7]. Available from: http:// www.meic.go.cr/ inec. Accessed June, 2000.

23. Krueger RA. Focus groups: a practical guide for applied research. 2nd edition. Thousand Oaks, California: Sage Publications; 1994.

24. McCormick KF. Attitudes of primary care physicians toward corporal punishment. JAMA 1992; 267(23):3161-3165.
25. Thompson RA, Christiansen EH, Jackson S, Wyatt JM, Colman RA, Peterson RL, et al. Parent attitudes and discipline practices: profiles and correlates in a nationally representative sample. Child Maltreatment 1999;4:316-330.

26. Wissow LS, Roter D. Toward effective discussion of discipline and corporal punishment during primary care visits: findings from studies of doctor-patient interaction. Pediatrics 1994;94(4 Pt 2):587-593.

27. Wissow LS, Roter D, Wilson MEH. Pediatrician interview style and mothers' disclosure of psychosocial issues. Pediatrics 1994; 93(2):289-295.

28. Kaluzny AD. Implementation of prevention and early detection activities: selected organizational perspectives. In: Hibbard H, Nutting PA, Grady ML, eds. Conference proceedings. Primary care research: theory and methods. Rockville, Maryland, United States: Agency for Health Care
Policy and Research; 1991. p. 197-202 (AHCPR publication no. 91-34).

29. Goodman RM, Steckler A, Kegler MC. Mobilizing organizations for health enhancement. In: Glanz K, Lewis FM, Rimer BK, eds. Health behavior and health education: theory, research, and practice. 2nd ed. San Francisco: Jossey-Bass Publishers; 1997. p. 287-312.

30. Morris JL, Johnson CF, Clasen M. To report or not to report: physicians' attitudes toward discipline and child abuse. Am J Dis Child 1985;139(2):194-197.

Manuscript received 13 October 1999. Revised version accepted for publication on 10 July 2000.

\section{ANNEX 1}

\section{CUESTIONARIO PARA PADRES}

Estamos tratando de apoyar a familias en su importante y muchas veces difícil tarea de criar y enseñar sus niños, por eso le solicitamos que responda este cuestionario. La información que Ud. proporcione será de gran utilidad y es confidencial.

Por favor, registre los siguientes datos:

1. Usted es, respecto al niño que viene a control (marque con un círculo):
a. madre
b. padre
c. abuelita
d. otro familiar
e. cuidadora

Respecto a la madre del niño (si no es viviente, continúe con el numero 5):

2. Su edad: años

3. Su estado civil (marque con un círculo)
a. soltera
b. casada
c. viuda
d. separada
e. divorciada
f. conviviente

4. Su ultimo curso escolar aprobado

Respecto a la casa del niño:

5. El padre vive con el niño:

a. Sí b. No

6. Número de niños que viven en la casa:

7. Número de adultos que viven en la casa:

- Por favor, lea cuidadosamente y marque con un círculo la alternativa que le parezca más adecuada. La situación es así: un niño entre 2 y 5 años se arranca a la calle por donde pasan muchos autos y micros.
8. ¿Alguna vez le ha pasado con su hijo?
a. nunca
b. a veces
c. con frecuencia

En esta situación, según Ud., los padres deberían:

9. Hablarle y explicarle por qué no debe salir solo a la calle

$\begin{array}{lll}\text { a. nunca } & \text { b. a veces } & \text { c. siempre } \\ \text { a. nunca } & \text { b. a veces } & \text { c. siempre } \\ \text { a. nunca } & \text { b. a veces } & \text { c. siempre }\end{array}$

11. Pegarle si el niño no obedece

a. nunca

b. a veces

c. siempre

- Por favor, lea cuidadosamente y marque con un círculo la alternativa que le parezca más adecuada. La situación es así: un niño entre 2 y 5 años pelea y les pega a otros niños.

12. ¿Alguna vez le ha pasado con su hijo?

a. nunca

b. a veces

c. con frecuencia

En esta situación, según Ud., los padres deberían:

13. Hablarle y explicarle por qué no debe pelear ni pegar a otros niños

14. Separarlo de los otros niños

15. Pegarle si el niño no obedece

$\begin{array}{ll}\text { a. nunca } & \text { b. a veces } \\ \text { a. nunca } & \text { b. a veces }\end{array}$

c. siempre

a. nunca

b. a veces

c. siempre

- La situación es así: un niño entre 2 y 5 años no obedece a sus padres cuando lo mandan a la cama.
16. ¿Alguna vez le ha pasado con su hijo?
a. nunca
b. a veces
c. con frecuencia
En esta situación, según Ud., los padres deberían:
17. Hablarle y explicarle por qué debe irse a la cama
18. Llevarlo a la cama y acostarlo aunque no quiera
a. nunca
a. nunca
a. nunca
b. a veces
b. a veces
c. siempre
c. siempre
19. Pegarle si el niño no obedece
a. nunca b. a veces
c. siempre 
Habitualmente es necesario controlar el comportamiento de los niños.

- Por favor, señale con que frecuencia usted hace lo siguiente:

20. felicitarlo cuando se porta bien

21. ignorarlo por un rato cuando se porta mal

22. pegarle cuando se porta mal

23. quitarle un juguete, un dulce, no dejarlo salir, no llevarlo de paseo cuando se porta mal

24. conversar y razonar con el niño cuando se porta mal

25. mandarlo afuera, sacarlo a otra habitación o al patio durante unos minutos cuando se porta mal

26. retarlo cuando se porta mal

27. hacerle cariño, darle un beso cuando se porta bien

28. gritarle o amenazarlo cuando se porta mal

\begin{tabular}{ccc} 
nunca & a veces & siempre \\
\hline $\mathrm{a}$ & $\mathrm{b}$ & $\mathrm{c}$ \\
$\mathrm{a}$ & $\mathrm{b}$ & $\mathrm{c}$ \\
$\mathrm{a}$ & $\mathrm{b}$ & $\mathrm{c}$ \\
$\mathrm{a}$ & $\mathrm{b}$ & $\mathrm{c}$ \\
$\mathrm{a}$ & $\mathrm{b}$ & $\mathrm{c}$ \\
$\mathrm{a}$ & & \\
$\mathrm{a}$ & $\mathrm{b}$ & $\mathrm{c}$ \\
$\mathrm{a}$ & $\mathrm{b}$ & $\mathrm{c}$ \\
$\mathrm{a}$ & $\mathrm{b}$ & $\mathrm{c}$ \\
$\mathrm{a}$ & $\mathrm{b}$ & $\mathrm{c}$
\end{tabular}

- Por favor, señale si usted piensa que hacer lo siguiente es útil o efectivo para controlar el comportamiento de los niños:

29. felicitarlo cuando se porta bien

30. ignorarlo por un rato cuando se porta mal

31. pegarle cuando se porta mal

32. quitarle un juguete, un dulce, no dejarlo salir, no llevarlo de paseo cuando se porta mal

33. conversar y razonar con el niño cuando se porta mal

34. mandarlo afuera, sacarlo a otra habitación o al patio durante unos minutos cuando se porta mal

35. retarlo cuando se porta mal

36. hacerle cariño, darle un beso cuando se porta bien

37. gritarle o amenazarlo cuando se porta mal

nun

- Por favor, marque con un círculo la alternativa que corresponda:

38. ¿Ha tenido necesidad de preguntarle a alguien qué hacer para que el niño le obedezca?

a. nunca a veces siempre

Si ha tenido que preguntar a alguien, marque con una cruz a quien o quienes ha preguntado:

39. _. A una vecina o amiga

40. - A un vecino o amigo

41. - A los padres

42. - A un hermano/hermana

43. - A otro familiar

44. - A la profesora o profesor del niño

45. A un cura o sacerdote

46. — A algún profesional del consultorio

47. - A la madre o abuela de otro niño en la sala de espera del consultorio

48. — Programa de radio, T.V.

49. Buscó en una revista o libro

50. — Otro (especifique)

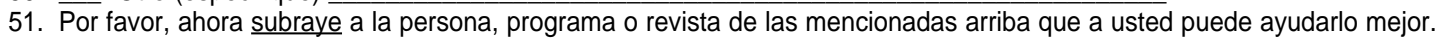

- Los siguientes son preocupaciones comunes de padres. Marque con el número:

1 = la más importante

2 = la segunda más importante ...

y continúe hasta el 5 para la preocupación menos importante.

52. __ Accidentes

53. — Agresividad

54. _ Alimentación

55. - Sexualidad

56. — Control de esfínteres

57. _ Otras: (especifique):

- Si alguna vez preguntó a uno o varios profesionales del consultorio para saber como hacer que el niño le obedezca, marque de quién o quienes recibió información y la utilidad de ésta:

\begin{tabular}{lccc} 
& no preguntó nunca & preguntó y recibió información útil & preguntó pero no recibió información útil \\
\cline { 2 - 4 } 58. Médico & $\mathrm{a}$ & $\mathrm{b}$ & $\mathrm{c}$ \\
59. Enfermera & $\mathrm{a}$ & $\mathrm{b}$ & $\mathrm{c}$ \\
60. Matrona & $\mathrm{a}$ & $\mathrm{b}$ & $\mathrm{c}$ \\
61. Asistente Social & $\mathrm{a}$ & $\mathrm{b}$ & $\mathrm{c}$ \\
62. Auxiliar & $\mathrm{a}$ & $\mathrm{b}$ & $\mathrm{c}$ \\
63. Otro & & $\mathrm{b}$ & $\mathrm{c}$ \\
(64) ¿quién?: & $\mathrm{a}$ & &
\end{tabular}




\section{CUESTIONARIO PARA PROFESIONALES DEL CONSULTORIO DE SALUD}

Se está realizando este estudio para saber qué piensan los profesionales acerca del trabajo de salud en el área de la consejería en temas de familia con los beneficiarios directos del consultorio. Para esto le solicitamos que responda este cuestionario, que es anónimo y cuya información puede ser de una gran utilidad para orientar el trabajo en este campo.

1. En su práctica clínica, ¿le preguntan los padres o familiares por problemas, dudas o le piden consejo en relación al control del comportamiento de los niños y niñas?
a. nunca
b. a veces
c. frecuentemente

2. Cuando le consultan acerca del control de la conducta de los niños, ¿expresan los padres preocupación por estar castigando físicamente al niño?
a. nunca
b. a veces
c. frecuentemente

3. Cuando le preguntan sobre problemas, dudas o le piden consejo, ¿cuál es la edad más frecuente de los niños?
a. menor de 2 años
b. entre 2 y 4 años
c. entre 4 y 6 años

- Los siguientes son preocupaciones comunes de padres. Marque con el número:

1 = la más importante

2 = la segunda más importante ...y continúe hasta el 5 para la preocupación menos importante.

4. Accidentes

5. _ Agresividad

6. _ Alimentación

7. Sexualidad

8. — Control de esfínteres

9. — Otras: (especifique)

10. ¿Cree usted que las condiciones de atención son apropiadas para aconsejar a los padres acerca de cómo controlar el comportamiento del niño?
a. Sí
b. No

Si su respuesta es no, ¿qué condiciones habría que modificar para realizar mejor el consejo a los padres? Marque con una cruz todas las condiciones que correspondan.

11. Duración o rendimiento de la actividad

12. — La frecuencia o concentración de la actividad

13. El espacio físico

14. _ Se requiere una atención sin la presencia del niño

15. Es preferible una atención grupal

16. __ Otros, indique cuales:

17. Cuando surge este tema en la consulta, la formación y experiencia que Ud. posee, ¿son suficientes para responder adecuadamente a las demandas de consejo?
a. Sí
b. No

18. ¿Piensa Ud. que es importante acceder a capacitación que mejore las competencias para el consejo?
a. Sí
b. No

Si su respuesta es sí, ¿qué tipo de capacitación considera usted más importante? Marque con una cruz todas que correspondan.

19. Psicología evolutiva del niño

20. — Técnicas de resolución de conflictos

21. Técnicas de manejo conductual

22. __ Técnicas de autocontrol y relajación para adultos

23. — Los derechos del niño

24. Prevención del maltrato infantil

25. — Detección y derivación de problemas de salud mental en niños y adultos

26. Técnicas de manejo de entrevistas

27. - Otro (especifique):

28. ¿Piensa usted que aconsejar en este tema forma parte de sus responsabilidades profesionales?
a. Sí
b. No

29. Si su respuesta es sí o no, ¿qué otras profesionales o organizaciones deberían asumirlo?

b.

30. ¿Se sentiría bien ofreciendo consejo sin que se lo soliciten expresamente?
a. Sí
b. No

31. ¿Existe demanda explícita de consejo?
a. Sí
b. No

32. Usted es:
a. auxiliar
b. asistente social
c. enfermera
d. matrona
e. médico
f. otro: ¿quién? 
RESUMEN El castigo corporal representa una forma de violencia que acarrea consecuencias mentales adversas en el corto y largo plazo. No obstante, es una de las formas más frecuentes de violencia personal y en muchos casos comienza cuando el niño aún no ha

Los padres y el castigo corporal: intervenciones de atención primaria en América Latina cumplido un año de edad. El objetivo del presente estudio fue determinar la factibilidad de utilizar a proveedores de atención primaria del sector público para explicar a los padres que hay otras opciones diferentes del castigo corporal. El estudio tuvo un diseño cualitativo y se valió de grupos de enfoque y formularios de encuesta para padres y proveedores de atención en seis centros ambulatorios que fueron elegidos como muestra representativa de los consultorios públicos de Costa Rica y de la zona metropolitana de Santiago, Chile. Los datos se recolectaron en 1998 y 1999. En los grupos de enfoque y las encuestas los padres expresaron diferentes opiniones sobre el castigo corporal. La mayoría reconocieron que la práctica estaba difundida, pero la colocaron en la lista de conductas punitivas que menos les gustaban. Su frecuencia mostró una correlación positiva con la creencia en su efectividad por parte de los padres y una correlación inversa con la satisfacción de los padres con la conducta de sus hijos. Algunos padres querían aprender más acerca de las formas de disciplinar a los hijos; otros querían que se les ayudara a sobrellevar las presiones de la vida que, según ellos, los hacían recurrir al castigo corporal. Los padres dijeron haber acudido a otros miembros de la familia como fuentes de información sobre la disciplina de los hijos con mayor frecuencia que a proveedores de atención de salud. A algunos padres les parecía que estos proveedores siempre andaban con demasiada prisa y que no poseían conocimientos suficientes para darles buenos consejos. Por otra parte, los proveedores de atención se sentían poco preparados para contestar las preguntas de los padres, pero muchos expresaron el deseo de recibir capacitación adicional. Tanto los padres como los proveedores de servicios estuvieron de acuerdo en que las limitaciones de tiempo, espacio y recursos planteaban barreras que impedían que se hablara del castigo de los hijos en el consultorio. A muchos padres y proveedores les gustaría que se creara un programa sobre el castigo corporal en el contexto de la atención primaria. Un programa de esa naturaleza tendría que adaptarse a las diferencias locales en cuanto a las actitudes de los padres y el personal y a la organización de los consultorios. Los proveedores de atención de salud necesitan un mayor adiestramiento sobre la disciplina de los niños y deben adquirir las habilidades indispensables para comunicarse con los padres sobre la conducta de sus hijos. 